\title{
Analysis of Mathematical Problem Solving Ability in STEM - Problem Based Learning Viewed by Students' Self-Confidence
}

\author{
E Syabila $^{1}$, A T Prayitno ${ }^{2}$, M Riyadi $^{3}$ \\ ${ }^{123}$ Department of Mathematics Education, Faculty of Teacher Training and Education. [Kuningan \\ University] \\ \{esasyabila0@gmail.com, anggar.titis.prayitno@uniku.ac.id,mohamad.riyadi@uniku.ac.id\}
}

\begin{abstract}
The purpose of this study was to describe the STEM - PBL process, the levels of students' self-confidence, and students' mathematical problem-solving abilities according to its level in senior high school. The research method is a qualitative method. The subjects of this study were six students who were chosen by two students for each level of self-confidence by purposive sampling. Analysis of mathematical problemsolving abilities based on the stages of problem-solving according to Polya. The data were collected through a self-confidence measuring questionnaire, mathematical problem-solving abilities test, and interviews. The results showed that the implementation of STEM - PBL applied a silo approach to the material of the sine rule, cosine rule, and area of the triangle. Students were guided by the teacher to solve problems online. The learning process can still encourage students to take an active role in every learning activity so that the results of the study show that the average student is included in the moderate level of self-confidence category an d only a few students with low self-confidence. According to the results of the test of mathematical problem-solving abilities in terms of students' self-confidence, it shows that the first, students with high self-confidence have better problem-solving abilities than other levels of self-confidence, which a good problem solver and routine problem solver, the second, students with moderate and low self-confidence were both in the naive problem solver category but students with moderate self-confidence showed better mean scores.
\end{abstract}

Keywords: Mathematical Problem; STEM; Problem Based Learning

\section{Introduction}

Mathematics is a discipline that is closely related to problem solving and has an important role in education. Problem solving ability is a cognitive aspect of learning mathematics. In addition, problem solving ability is very important part of the mathematics curriculum. Problem-solving ability is a person's ability to solve various types of problems, including routine, non-routine, applied, non-routine, non-applied, and non-applied routine problems [1]. The results of The Program for International Student Assessment (PISA) show that Indonesia is ranked 73 out of 79 participated countries [2]. The ranking also show that Indonesia has a low ability in the field of mathematics, especially problem solving abilities as revealed by [3] that mathematics is closely related to problem solving. This can be influenced by several factors, including factors that come from within and outside the student. One of the factors that comes from within is student's self-confidence. Research by [4] states that between problem-solving abilities and students' self-confidence shows a significant relationship. This 
shows that self-confidence can be used as a benchmark to measure students' mathematical problem solving abilities. Another factor that comes from outside is learning activities at school that can also be one of the determinants of student learning success. Such a research by [2] that a country's ranking in the PISA index is used as a benchmark as a determinant of the quality of education based on international needs. Based on the PISA index, it can be seen that the quality of Indonesian education cannot be said to meet international needs. This is a reference for Indonesia to always develop education through the development of a national curriculum.

Some of the efforts made by the government to improve the quality of education are by developing a STEM approach that can be supported by various scientific learning models [5]. This encourages SMAN 3 Kuningan to apply STEM learning that is supported by the PBL model in its implementation. STEM - PBL learning is a learning activity that integrates science, technology, engineering, and mathematics simultaneously to train student creativity through problem solving processes [6]. Based on the description above, this study aims to analyze the mathematical problem-solving abilities of students who have taken STEM - PBL learning in terms of self-confidence. The problem solving stage that becomes the guideline is the stage according to [7], namely (1) understanding the problem, (2) making a resolution plan, (3) implementing the plan, and (4) checking again. The self-confidence aspect used is an indicator according to Lauster in [8], including (1) believing in one's own abilities, (2) acting independently in making decisions, (3) having a positive self-concept, (4) having the courage to express opinions. This research needs to be done because SMAN 3 Kuningan has developed STEM - PBL learning.

\section{Method}

This research was conducted at SMA Negeri 3 Kuningan on the material of trigonometry sub material rules of sine, cosine, and area of triangle. The research subjects selected by purposive sampling technique were 6 out of 35 students from class X MIPA 3 as the research class. The research method used in this study is a qualitative method with a descriptive type of research that aims to describe in more detail the mathematical problem solving abilities of students who have taken STEM - PBL learning by teacher at school by making selfconfidence as the reviewer. The instruments used were in the form of a self-confidence measuring questionnaire and a test of mathematical problem-solving abilities, as well as an interview guide to selected subjects. The questionnaire used was based on the self-confidence indicator according to Lauster, while the test instruments and interview guidelines were arranged to meet the indicators at the problem solving stage according to [7].

The number of mathematical problem solving ability test are three questions made according to the indicators at the Polya's problem solving stage and focus on the class $\mathrm{X}$ trigonometry material, then the self-confidence questionnaire of 30 statements scales. Based on the test results for the research class, 6 subjects were selected representing 3 levels of selfconfidence, namely high, medium, and low, where each level was represented by 2 subjects. The data from the research results were then analyzed through 3 stages according to Miles \& Hubeman in [9], namely data reduction so that 6 subjects were selected, the presentation of data arranged in the form of descriptive text, images, and tables supporting the research results, and finally made inferences about problem-solving ability mate ma tis every subject selected in terms of their self-confidence. 


\section{Result and Discussion}

\subsection{STEM - PBL Learning}

The implementation of STEM - PBL learning on the rules of sine, cosine, and area of a triangle material is carried out based on the network (online). Problem-based learning model was selected based on teacher considerations so that students are always trained to be able to solve problems. [10] explain that the application of problem-based learning is proven to be more effective in improving problem-solving abilities compared to non-problem-based learning. In addition, the use of the PBL model in mathematics lessons in class X MIPA at SMAN 3 Kuningan is to support the implementation of effective STEM learning.

The STEM approach pattern used is the silo approach pattern. [6] describes the silo as an approach that emphasizes the acquisition of knowledge compared to technical capabilities. The silo approach is characterized by teacher-driven learning. He also added that the purpose of the silo approach is to increase student knowledge which drives research activities. The most visible thing from STEM activities that are applied to online learning in class X MIPA 3 SMAN 3 Kuningan is that the teacher encourages students to carry out research activities in solving the problems given. Studies have found that teacher can't guarantee that STEM is carried out because they can't see learning activities directly. More recently [11] investigated that the weakness of STEM learning with the silo approach is that it has a tendency to reduce the expected meaning of STEM learning.

\subsection{Self-confidence}

Percentage composition and distribution is based on the level of self-confidence 35 students of class X MIPA SMAN 3 Kuningan who take the test through a questionnaire presented at the Table 1 .

Table 1. Percentage of The Students' Self-Confidence Level Spread

\begin{tabular}{ccc}
\hline Self-confidence Level & Frequency & Percentage \\
\hline High & 7 & $20 \%$ \\
Medium & 24 & $68,6 \%$ \\
Low & 4 & $11,4 \%$
\end{tabular}

The results of these measurements show that the average grade X MIPA 3 student of SMAN 3 Kuningan is in the medium category at the self-confidence level. The implementation of STEM learning that has been applied in schools is very much supported by students' self-confidence. The personality of students with medium self-confidence is to support the implementation of STEM - PBL learning which is applied at SMAN 3 Kuningan.

\subsubsection{Student's mathematical problem solving ability with high self-confidence}

The results of the study on 2 selected subjects, namely NP and VN, showed that both of them had the same personality but $\mathrm{VN}$ could only fulfill all problem solving indicators in question number 1 only. Different from NP that can carry out all indicators on each questions. Overall, it can be concluded that NP is included in the good problem solver category according to Williamson in [12]. Some of the characteristics of good problem solvers according to Williamson that have been shown by NP include she using a variety of strategies in the problem-solving process. She also shows the ability to think metacognitive in verbal and written communication. In addition, she obtained a high mathematical problem solving ability test score and good verbal communication skills.

Finally, she shows a confident attitude and confidence in the answers she gives in solving problems. While some of the characteristics shown by $\mathrm{VN}$ are the features of routine problem 
solver. She using strategy systematically, she showed metacognitive abilities in verbal communication only, there is no attempt to check the completion, and sometimes she feels unsure of the answers. It is because she is not sure about her capabilities. Based on the description above, it can be concluded that this is in accordance with what was stated by [13] that students with high self-confidence have high problem solving abilities as well.

\subsubsection{Students' mathematical problem solving ability with medium self-confidence}

The results of research on $\mathrm{HK}$ and $\mathrm{AN}$ as selected subjects with medium self-confidence were obtained that both of them were considered naive problem solvers according to Williamson. Both subjects cannot solve the problems given to each problem. Some of the characteristics of the naive problem solver shown by HK are in the form of errors that are made in almost all stages of problem solving. Additionally, she points out its error in using the same method to solve different problems. While the characteristics shown by AN are mistakes that have been made at almost all stages of problem solving. In addition, she shows its error in using the same method to solve different problems. She also made pseudo plan and pseudosolution so that it failed to solve 2 problems.

The results of research on them indicate that a wrong understanding will have an impact on the whole problem-solving process. In addition, unsuitable plans can result in unsuitable solutions as well. This is in line with what was expressed by Polya in [12] which states that students cannot solve the problem if they do not understand the problem. Medium selfconfidence levels of both subjects are shown by the subject's doubts about the answers given and the results of the mathematical problem solving ability test results are also not good. The result is in the line with [13] which revealed that mathematical problem solving abilities are influenced by the self-confidence possessed by students. When self-confidence is high, the problem solving ability will be good [14]. The self-confidence possessed by them can be said to be one of the factors causing the poor results of mathematical problem solving that have been carried out.

\subsubsection{Student's mathematical problem solving ability with low self-confidence}

The results of research on DS and YS who were selected subjects with low self-confidence found that both of them were considered naive problem solvers according to Williamson. They were only able to solve 1 problem and only fulfilled 1 indicator on the other 2 problems. Some characteristics of naive problem solver that is indicated by them is the tendency of them to made a mistake at almost all stages of problem solving by Polya and use the same method to solve different problems. They also showed uncertainty about the answers given. The low level of self-confidence in the two subjects was shown with no effort of them to explore their knowledge so as not to use the concepts that have been used in other problems.

The results of the questionnaire test also showed that they were students who did not actively speak in front of the class, so they were not confident when being interviewed. According to [15], self-confidence is very influential on communication skills. Good communication skills can make everyone able to convey every idea and thought effectively. It shows to not unbelief self is an impact on the results of mathematical problem solving ability test two subjects. 


\section{Conclusion}

Based on the research that has been done, it can be concluded that STEM - PBL learning which is carried out based on the network (online) is applied with a silo approach pattern. This approach pattern is applied because it requires the teacher to give more control over student activities online. In addition, the teacher can't guarantee that STEM is carried out because they can't see learning activities directly so that it can reduce the expected meaning of STEM learning. However, STEM - PBL learning with a silo approach pattern can still support each other with students' self-confidence because there are problem-solving activities in the learning process that is being carried out.

The analysis has shown students who have participated in STEM learning - PBL school average included into the medium category of being in level self-confidence. Based on the average value of mathematical problem solving ability tests and research conducted on subjects chosen by the students with high self-confidence level get the highest average score compared to students with medium and low self-confidence level. This research has shown that self-confidence give the effect to the success of student learning, especially in developing mathematical problem solving ability.

\section{References}

[1] K. E. Lestari, and M. R. Yudhanegara, "Penelitian Pendidikan Matematika," (Bandung: PT Refika Aditama), 2015.

[2] I. D. Pratiwi and H. Laksmiwati, "Kepercayaan Diri dan Kemandirian Belajar Pada Siswa SMA Negeri X", Jurnal Psikologi Teori \& Terapan, Vol. 7(1), pp. 43-49, 2016.

[3] K. S. Lestari, S. Nurjanah, and L. S. Zanthy, "Analisis Kemampuan Pemahaman Dan Pemecahan Masalah Matematik Siswa Smpn 36 Bandung Pada Materi Persamaan Linear Satu Variabel”, Jurnal Pembelajaran Matematika Inovatif, Vol. 2(3), pp. 107-118, 2019.

[4] P. N. Aisyah P N, N. Nurani, P. Akbar, and A. Yuliani A, "Analisis Hubungan Kemampuan Pemecahan Masalah Matematis Dan Self Confidence Siswa SMP”, Journal On Education, Vol. 1(1), pp. 58-65, 2018.

[5] Mifatahuzzakiyah, "Pengaruh Pendekatan Pembelajaran STEM terhadap Kemampuan Literasi Sains Peserta Didik Pada Konsep Jamur", (Universitas Islam Negeri Syarif Hidayatullah), 2018.

[6] J. S. Morrison, "STEM Education Monogroph Series: Attributes of STEM Education”, TIES. 2006.

[7] G. Polya, "How To Solve It", (America: Princeton University Press), 2004

[8] P. Lauster, "Personality Test", (Jakarta: PT. Bumi Aksara), 2015

[9] Sugiyono, "Metode Penelitian Kuantitatif, Kualitatif, dan R\&D", (Bandung: Alfabeta), pp. 247, 2015.

[10] J. E. Valdez and M. E. Bungihan, "Problem-Based Learning Approach Enhances The Problem Solving Skills In Chemistry Of High School Students", Journal of Technology and Science Education, Vol. 9(3), pp. 631, 2019

[11] Winarni, S. Zubaidah, and S. K. H, "STEM : Apa? Mengapa? dan Bagaimana?", Pros. Semnas Pend. IPA Pascasarjana UM, Vol. 1, pp. 976-982, 2016.

[12] J. P. Mairing, "Pemecahan Masalah Matematika", (Bandung: Alfabeta), 2018.

[13] Z. M. Ramdan, L. Veralita, E. E. Rohaeti, and R. Purwasih, "Analisis Self Confidence Terhadap Kemampuan Pemecahan Masalah Matematis Siswa Smk Pada Materi Barisan Dan Deret", AKSIOMA - JPM FKIP Universitas Muhammadiyah Metro, Vol. 7(2), pp. 171-179, 2018.

[14] N. Fitriani, "Hubungan Antara Kemampuan Pemecahan Masalah Matematis Dengan Self Confidence Siswa SMP Yang Menggunakan Pendekatan Pendidikan Matematika Realistik”, Jurnal Euclid, Vol. 2(2), 2018. 
[15] A. Fakhiroh and S. Hidayatullah, "Pengaruh Percaya Diri Terhadap Keterampilan Berbicara", El Ibtikar, 2018.

[16] J. Ilmi and Y. Suharsono, "Self-Hypnosis Training to Improve Self-Confidence in Students for Speaking in Public", Atlantis Press, Vol. 128, pp. 1-6, 2017. 